\title{
The FOMC in 1982: De-emphasizing M1
}

\author{
DANIEL L. THORNTON
}

\begin{abstract}
T HE year 1982 was marked by rapid and variable growth of the monetary aggregates. The growth of M1, the narrow monetary aggregate, was up sharply from 1981, while M2 growth was slightly above the previous year's rate. Of the three targeted aggregates, only M3 growth was lower in 1982 than in 1981. Moreover, 1982 marked the first time since the Federal Open Market Committee (hereafter FOMC or Committee) adopted its new procedures in October 1979 that the fourth-quarter-to-fourth-quarter growth rate of $\mathrm{MI}$ accelerated. $^{1}$
\end{abstract}

As was the case in 1981, the Committee faced unusual uncertainties regarding the relative behavior of M1 and M2 during the year associated with various technical factors, regulatory changes and financial in novations. Furthermore, the income velocities of the monetary aggregates, especially that of $\mathrm{Ml}$, dechined relative to their historical norms. ${ }^{2}$ Because of these difficulties, the Committee had considerable discussion about the weight that should be assigned to MI

Note: Citations referred to as "Record" are to the "Record of Policy Actions of the Federal Open Market Committee" found in various issues of the Federal Reserve Bulletin.

${ }^{1}$ For a description of the operating procedure, see R. Alton Gilbert and Michael Trebing, "The FOMC in 1980: A Year of Reserve Targeting," this Review (August/September 1981), pp. 2-22, and Richard W. Lang, "The FOMC in 1979: Introducing Reserve Targeting," this Review (March 1980), pp. 2-25.

${ }^{2}$ The income velocity of a monetary aggregate is given by the ratio of nominal GNP to the aggregate. It indicates the number of times each unit of nominal money "turns over" in producing this year's final output. This conclusion about the record decline in velocity was based on the fact that Ml growth had been rapid in the first quarter compared with what would have been predicted on the basis of the actual behavior of nominal GNP and interest rates. This interpretation was supported by the growth in relatively lowinterest-yielding savings deposits. See "Record" (June 1982), pp. $366-67$. and M2 as a guide to policy. Ultimately, it decided to suspend setting explicit growth objectives for Ml during the fourth quarter of the year. This article will review the factors affecting the long-and short-run policy decisions of the Committee during 1982, including those leading up to the decision to suspend setting an explicit target for M1.

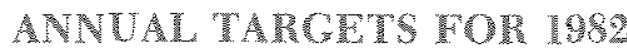

The Full Employment and Balanced Growth Act of 1978 (the Humphrey-Hawkins Act) requires the Board of Governors to transmit to Congress, each February and July, reports on the objectives for growth rate ranges for monetary and eredit aggregates over the current calendar year and, in the case of the July report, over the following calendar year as well. ${ }^{3}$ The Committee has chosen to establish ranges from the fourth quarter of the previous year to the fourth quarter of the current year. ${ }^{4}$

\footnotetext{
These ranges must be reported to Congress each Tebruary and July, although the Act provides that the Board and the Committee may reconsider the annual ranges at any time. The period to which the annul ranges apply, however, may not be changed. The base period that the Committee has chosen (the fourth quarter of the previous year) would remain the same even if the Committee decided to change the desired growth rates of the aggregates for the year.

Before 1979 , the Committee adopted one-year growth rates each quarter, and the base period for the annual targets announced each quarter was brought forward to the most recent quarter. This method resulted in a problem referred to as "base drift." Growth in aggregates above (below) an annual growth range in a quarter would raise (lower) the base level for calculating the next annual growth path. The specification of annual objectives in terms of calendar year growth rates, which eliminates the base drift prob. lem within a calendar year, does not solve this problem from one calendar year to the next, since new ranges are established from the end of each calendar year.
} 


\section{Organization of the Committee in 1982}

The Tederal Open Make, Commitee (TONO con

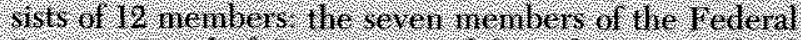

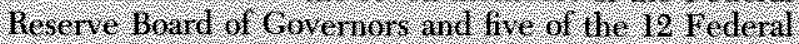
Resul le Banl vresidents. The C haminan of he Board of

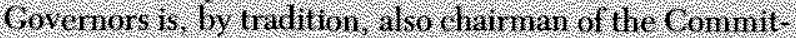

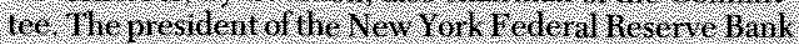

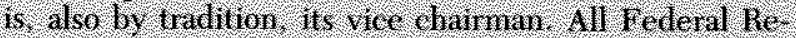

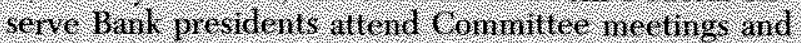

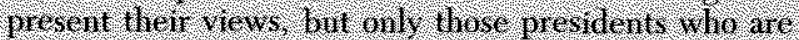

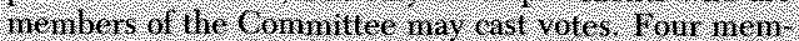

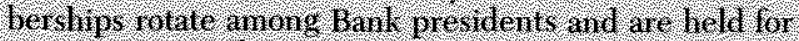

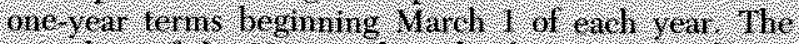

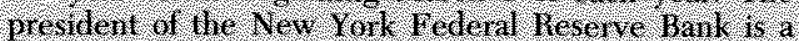
permunent voting nember of the o onmile.

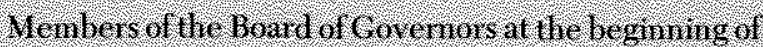

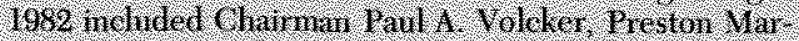

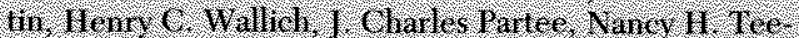

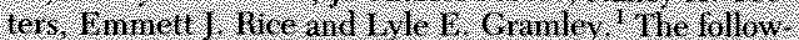

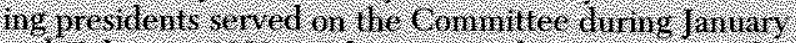

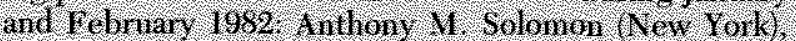

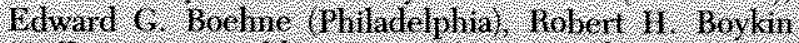
(Dallas) I. Gerald Cormgan Mrmeapolis) and Sils

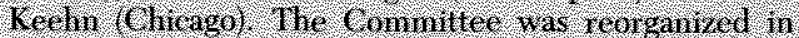

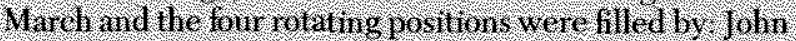

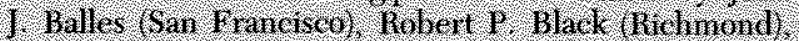

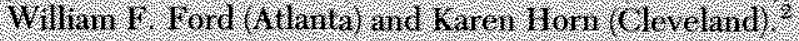

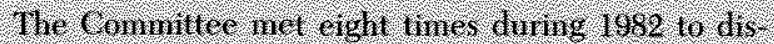
coss, aming onler things, economic trends and to decide

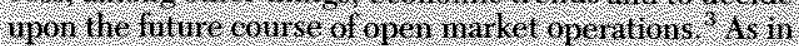
jrevious rears, hovever, tele phone or tel gram conshl.

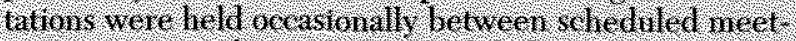

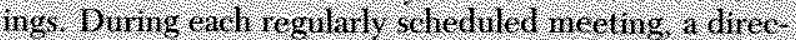

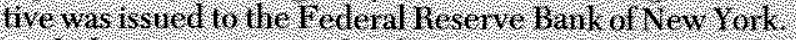

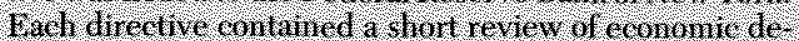
velopinents, line general eromomic goals songht by the

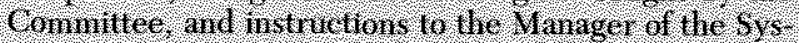

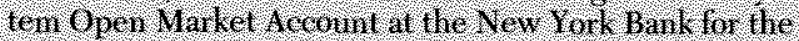

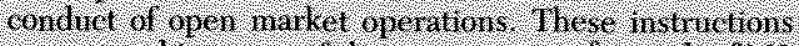
werc stated in te nus of shom term rates of growh of Wh and W2 that were comsidered to be consistent will desired honger num growh rates at the monetary aggre?

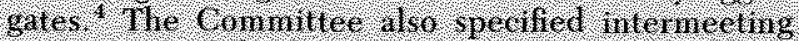
ranges for the federal find trate. Ihese ravges jrovide a

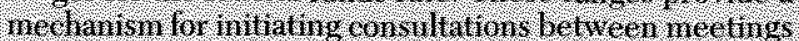
whenever it appears that die constramt on the fedenal

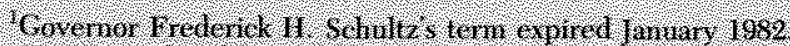

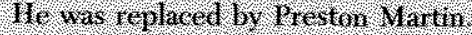

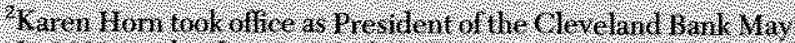

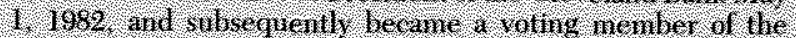
MOMC Mr. Wun wolded an atrmate ner wer in Marel.

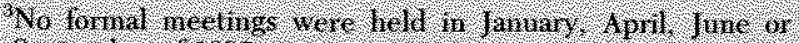
Septentier of 1982

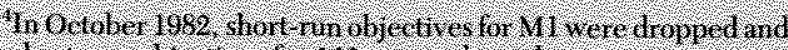
shot thin objectiver for Wh vere adepted find rate ts proving neonsistent will the objectives ter the behavior of the monetan aggregates:

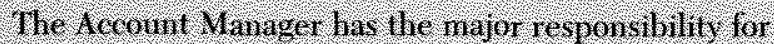

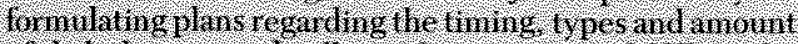

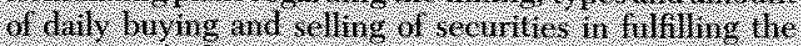
Conmitrees s litective. Wath woming the Ninager and

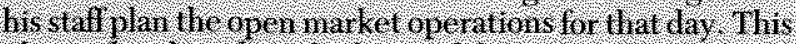

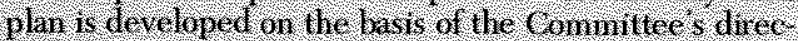
live, and the late d developments affecting nones and credil makket conditions, growhl of 1 ic nonetar aggre? gates and bath reserve conditions. The Marager ther

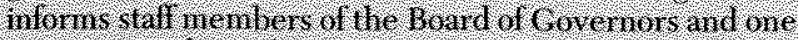
voling president buot present warket comditions an

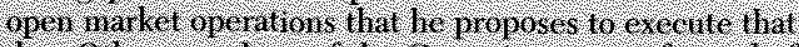

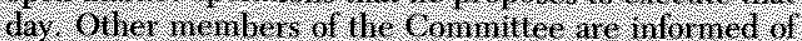

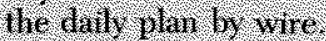

The divertives issued by lie Comimited and a sum.

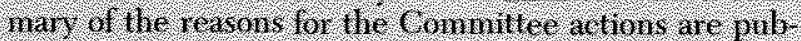
Isted in the Mecond of Pollev tctions of the Tederal

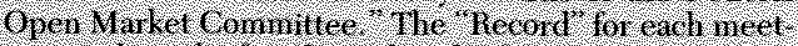

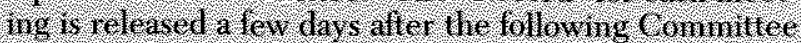

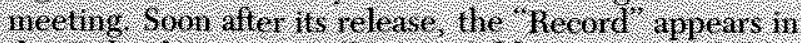

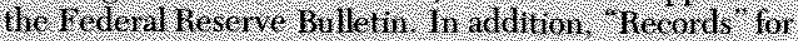

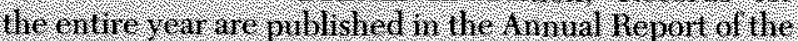

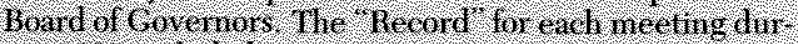
ins 1982 induled:

1) A staff suminary of recent economic developments

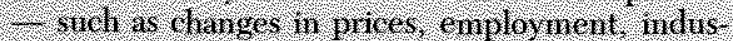

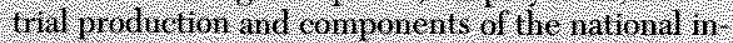

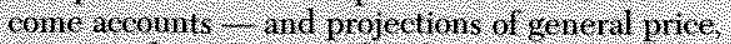

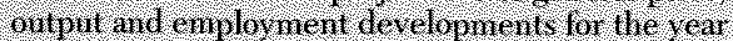
arads

2) I summary of recent ntemetional hinarial de velopments and Whe US Goregh Uade Walange.

3) A summary of recent credit market conditions and recent interest rate moventents:

4) A summary of oper market gperations, growth of numetay aggreghtes and hank reserves, and noney malket conditions sinec $\mathrm{h}$ c previous neeting

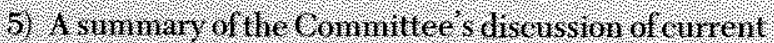
and prospective reonomic and finan tial conditions

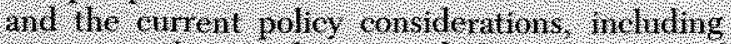
nomer narket condtions and he moventent of nonelary aggregates:

6) ronelisions of line connities.

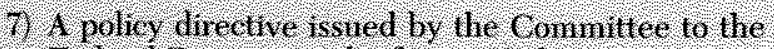
Teleral Reserve Bank of New Youl

8) (1) Ist of the nemiles' voting positions and any dissenting comments.

9) A description of any actions and consultations liat

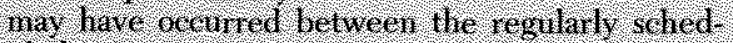
Wet nestings 


\section{Table 1}

FoMC Operating Ranges - 1982

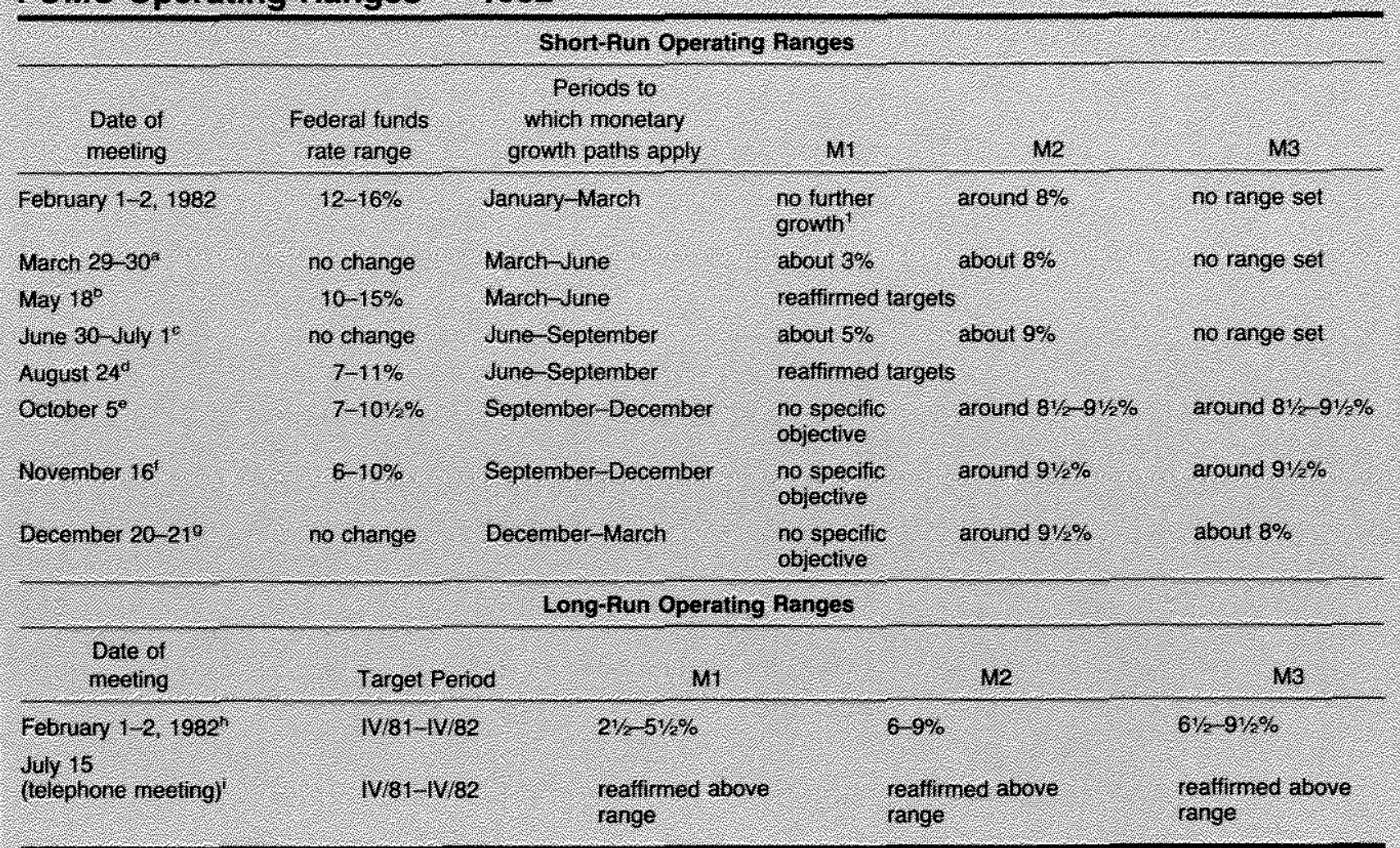

Arits December $198 \mathrm{t}$ meeting the Committee sel an objective for M1 of around 4 to 5 percent, however, the surge in M/ growhinuantray prompled the Commillee 10 set a tho tuther growh' objective at is r ebruary meeting

At its February meeting, the Committee completed the review, begun at its December 1981 meeting, of the annual targets for the monetary and credit aggregates for 1982. It remained committed to its longstanding goal of restraining the growth of money and credit to reduce further the rate of inflation. Nevertheless, Committee members disagreed about the precise ranges to set for the various monetary aggregates. Most members favored reaffirming the ranges for Ml that had been tentatively adopted at the July 1981 meeting. A substantial number, however, favored a somewhat higher range for M2 based on the belief that various developments during the year would likely boost the growth of M2 relative to M1. ${ }^{5}$ Also, it was generally agreed to give considerable weight to $\mathrm{M} 2$ in interpreting developments during the year. ${ }^{6}$

\footnotetext{
${ }^{5}$ At its midyear review of the annual ranges, the Committee establishes tentative ranges for the monetary aggregates for the next year - measured from the fourth quarter of the current year to the fourth quarter of the following year.

${ }^{6}$ See *'Record" (April 1982), pp. 232-33.
}

In setting its growth range for M1, the Committee argued that the growth in "other checkable deposits," which had accelerated during January and which was in large part responsible for the rapid January growth of $\mathrm{M} 1$, was likely to be temporary, and that the relationship between the M1 growth and the nominal GNP growth likely would be closer to its historical pattern during 1982. On this assumption, the Committee argued that it would be acceptable for M1 to grow at a rate near the upper end of its annual range during 1982. The Committee also expected that the growth of M2 would be high in its range, although somewhat below that of $1981 .^{7}$ At the end of the discussion, the Committee reaffirmed its tentative ranges for $\mathrm{Ml}$ and M2. These ranges are presented in table 1 .

\footnotetext{
${ }^{7}$ Indeed, the Committee believed that the growth in M2 might meet or exceed the upper end of its range if the personal savings rate grew more rapidly than anticipated, or if depository institutions attracted an exceptionally large flow of funds into IRAs from sources outside of M2. See "Record" (April 1982), p. 233.
} 


\section{Table 1 (continued) \\ Footnotes - Dissents to FomC Actions}

MUessis. Black and Wallch dissented from nis action because hey favored specitication of somewhal lower rates for monetary growh rom March to wune than those adopted by the Conmittes. Whieh would be associated with a relatively prompl retum of MI growth to its range for the year

Mir Black believed that conthued growth of MI above is longer run range for any extended period would adversely affect economic activity by exacerbaling inlationary expectations and weakening narkels for longer term securites, lor hal reason. he fell that il was paticulary important to resist ony surge in growh of $M$ t that might develop in April

In Mr Wallichs opmion, it would be desirable to restrain the pace of prospective recovery in economic activity consistent with senie redtction in the unenpioynent rate to sustain a degree of pressure for the continuation of the reduction in the underlying rate of niftation:

'Wis. Teeters dissented from this action because she favored specification of somewhat higher rates of monetang growth from March to lune

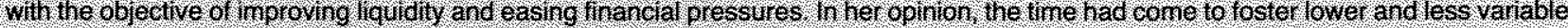
interest rates in order to enhance prospects for significant recovery in output and enploymont

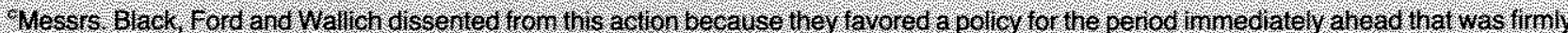

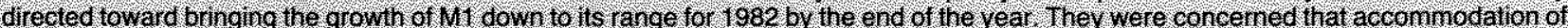

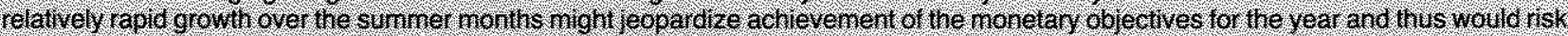
exacerbaling inflationary expectations. Accoldingly hey betieved that tendencies toward rapid monetary expansion in the moniths imnediately ahead should be net by greater pressires or bank reserve positbrs and in the noney narkel.

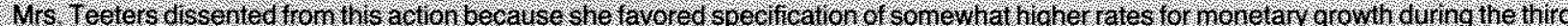

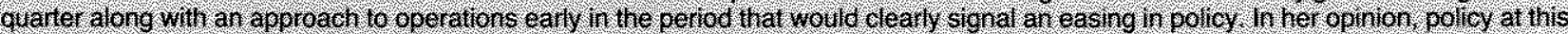

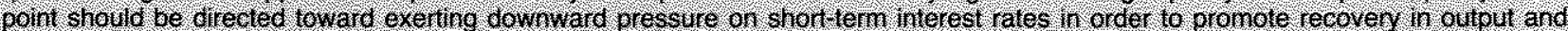
employment.

1. Walleh dissented tron this action because he favored an approach te operations early h he period that would lessen hhe chances of

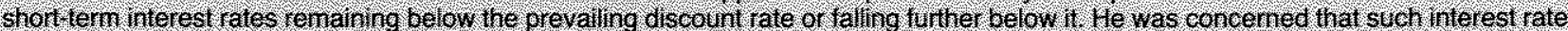
behaver would lend to accelerate nonetar, expansion and hat he necessary restrain of reserve growth to cub such expansion mght lead to a sizable rebound in short term rates with adverse inplications tor busness and consumer confidence

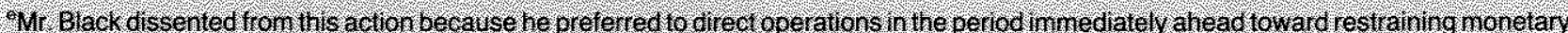

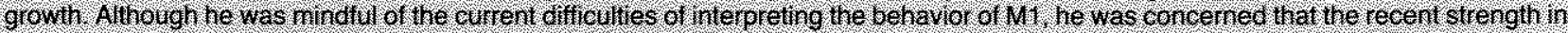

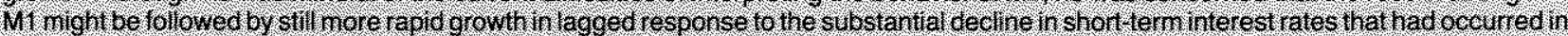
the summer. Which could regure oven more restriet ve operations later

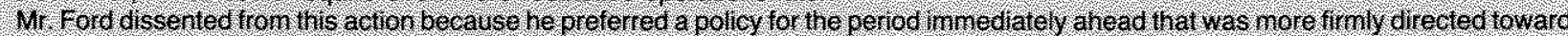
restraining monetary growth alliough he recognzed hat the behavior of Wh ir particular would be difficult to interprel he was concerted that the Commitees policy directive night be misine preled in ways hat could adversey affect pursuil of the Systems briger run antithilationary objectives, parlicularly in he context of a fighty expansive fiscal pollcy program.

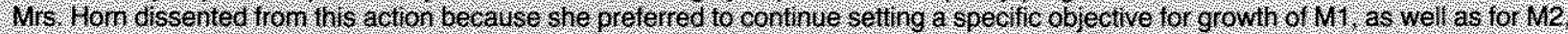

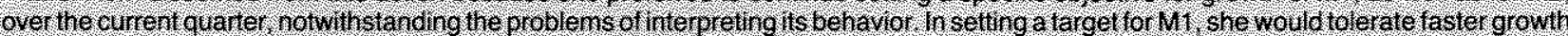

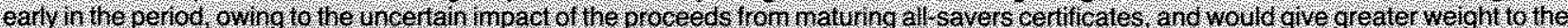
behavior of W2 for sone veeks affer the throduction of the hew instrument at depository instititions:

TM. Ford dissented hom his action because he believed that it ran the isk of complenenting werv large budgel defiels wh substantia

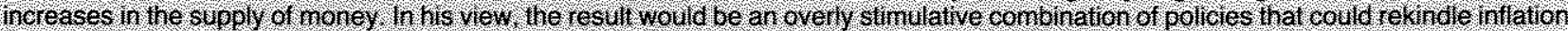
and drue up interest rales duing 1983 .

9M. Black dissented becalise he preterred to diect oblicy in the weeks immediately ahoad toward ensuling that the growth of Mi

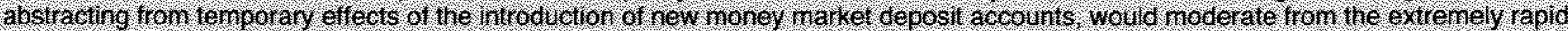

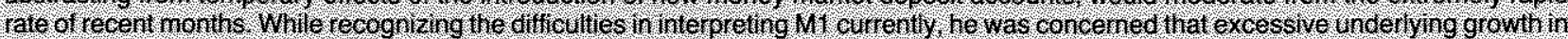
that aggregate inght reverse the progress achieved in recucing inflafion and intlationary expectations and lead to substantally Weaker narkets tor long term securites

Mr. Tord dissented from this ation because he continued to preter a policy to the current period that was hore firmly dirocted toward

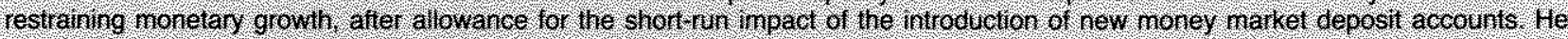
remahed concemed hat rapd expansion it the supply of honey logether with very large budget deficts would produce an ovenly stinulatve combination of policies that could rekndle filtation and intlationary expectalions and lead to higher interest ales oling 1983 and 1984

7Ws. Teeters dissented from this actibn because she befleved that sonewhat higher monetary growth over the year ahead was needed to promole a dequate expansionin econonnic activity and a rediction in the rate of uhemployment Specitically, she tavored a range for Mi that was at least 1 percentage poinl higher than that adopted by he commities and a range for Mz that provided for somewhat greater growth in the broader aggregate relative to that in $M$.

Mrs. Teeters dissented fron this action because she tavored an explict statement that growh of Wh above the upper end of the Commitee s range for $1982 \mathrm{by} 1$ percentage point, or even as nuch as $14 \%$ percentage points, night be acceptable. In her ophlon, It was

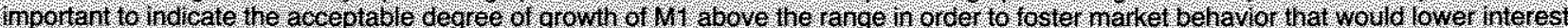
rates and enhance the prospects lor sustainng rocovery in output and enployment 


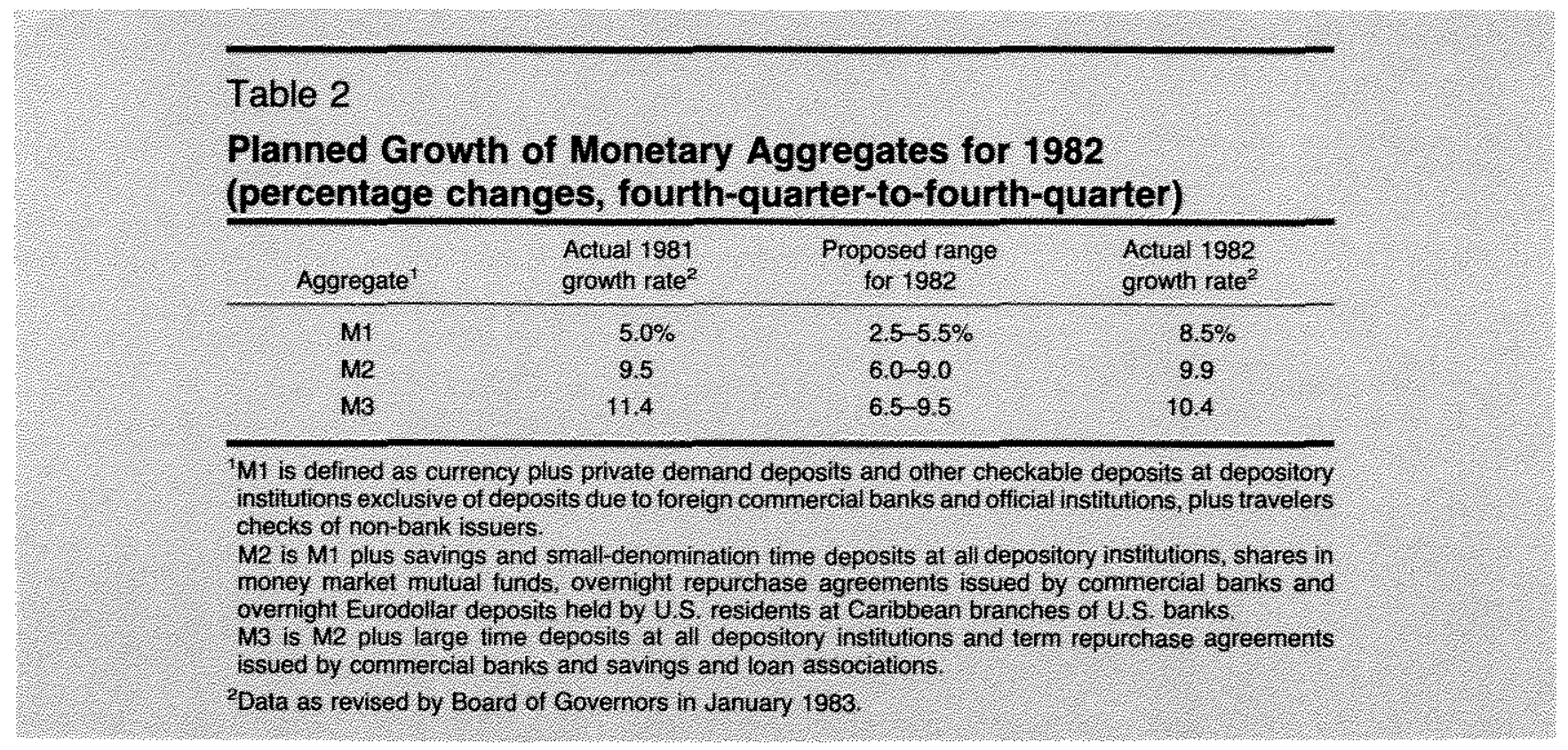

\section{Achad Moncy Growh in 1082}

As shown in table 2, all three of the monetary aggregates exceeded their target ranges during $1982 .{ }^{8}$ Their patterns of growth relative to their ranges, however, were considerably different, as can be seen in chart 1 . Both $\mathrm{M} 1$ and $\mathrm{M} 2$ were above their targeted ranges nearly all of the year. In contrast, M3 growth was within its range during the first half of 1982 and above it during the second half.

Although both M1 and M2 were above their target ranges throughout the year, their growth rates displayed different patterns. While the quarter-toquarter growth of M2 during 1982 was less stable than that of 1981, it was stable compared with the quarterto-quarter growth of M1. M1 grew rapidly in January and was fairly flat until July, when it began a growth spurt that accelerated markedly in October. This pattern of M1 growth was basically consistent with the Committee's short-run objectives for the year.

\section{SHOMT-RUN POLICY DIRECTVES HOR 1982}

The announced annual target ranges for the monetary aggregates provide a basis on which the FOMC

\footnotetext{
"The definition of $\mathrm{M} 2$ was changed effective February 14,1983 , to include tax-exempt money market funds and to exclude all IRA Keogh balances at depository institutions and money market mutual funds. These changes also affected M3. Thus, data available January 20, 1983, were used. The growth rates of M1, M2 and M3 will differ from those reported from revisions after February 14 , 1983.
}

chooses its short-run policy objectives during the year. The short-run policy directives, however, are the ones that influence the day-to-day implementation of monetary policy. The Committee issues these directives for implementation by the Manager of the Open Market Account at the Federal Reserve Bank of New York.

During 1982, the Committee specified short-run growth rates for M1, M2 and M3. It also specified intermeeting ranges for the federal funds rate as a mechanism for initiating further consultations in periods between regularly scheduled meetings. ${ }^{10}$ These intermeeting ranges and the actual federal funds rate are presented in chart 2 . The growth rate targets for the monetary aggregates and the intermeeting ranges for the federal funds rate that the Committee specified during 1982 appear in table 1.

As in the previous year, discussions pertaining to short-run policy decisions in 1982 were marked by considerable uncertainty about both the effect of various regulatory changes and financial innovations on the growth rates of the monetary aggregates and the

\footnotetext{
${ }^{9}$ The short-run growth rate target for Ml was dropped at the October meeting and a short-run target for M3 was introduced.

${ }^{10}$ If movements of the fecteral funds rate within the range appear to be inconsistent with the short-run objectives for the monetary aggregates and related reserve paths during the intermeeting period, the Manager of Domestic Operations at the Federal Reserve Bank of New York is to notify the Chairman, who in turn decides whether the situation calls for supplementary instructions from the Committee.
} 


\section{Chant! \\ Long-Run Operating Ranges for the Period IV/81-IV/82}

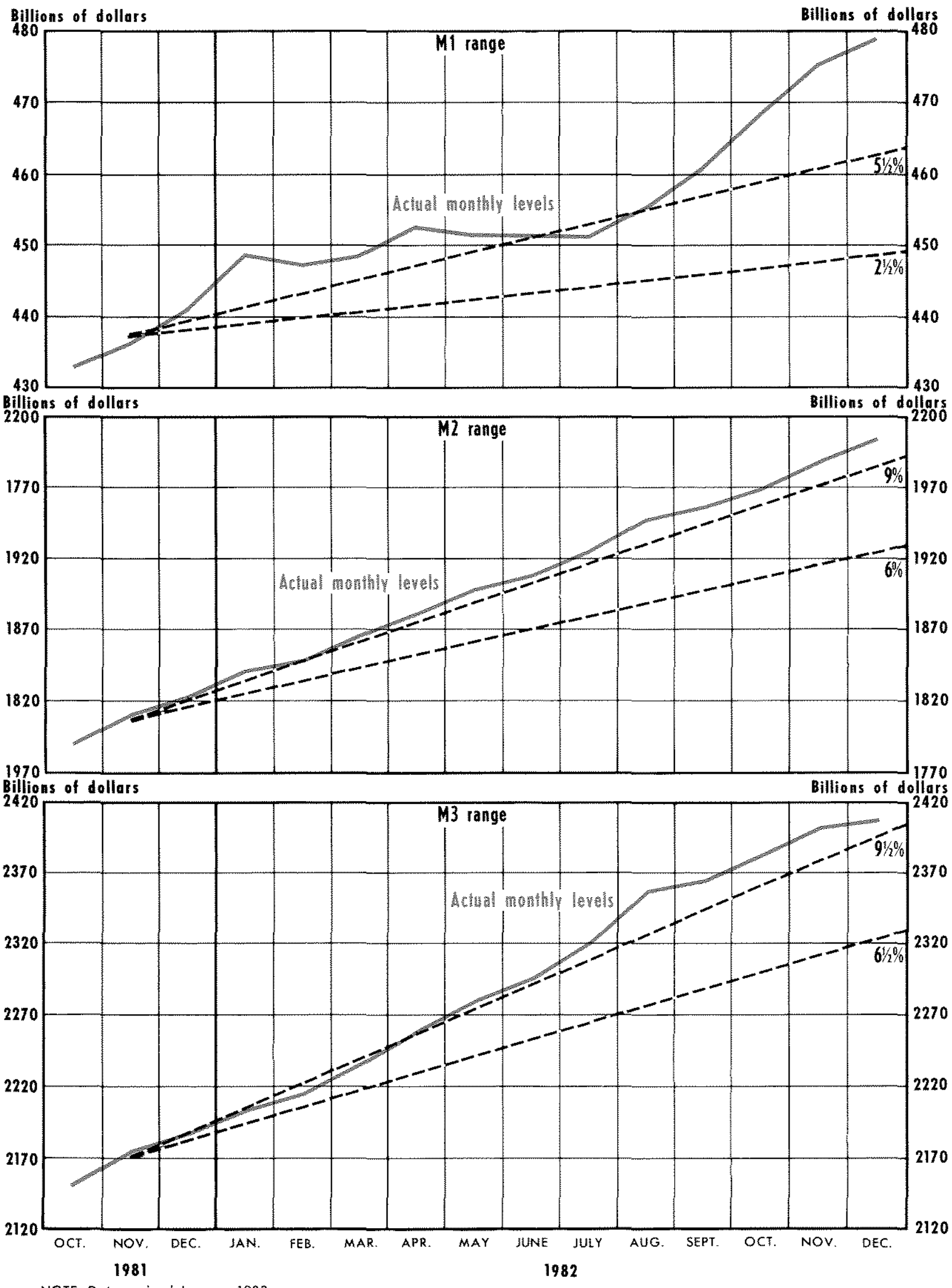

NOTE: Data revised January 1983 


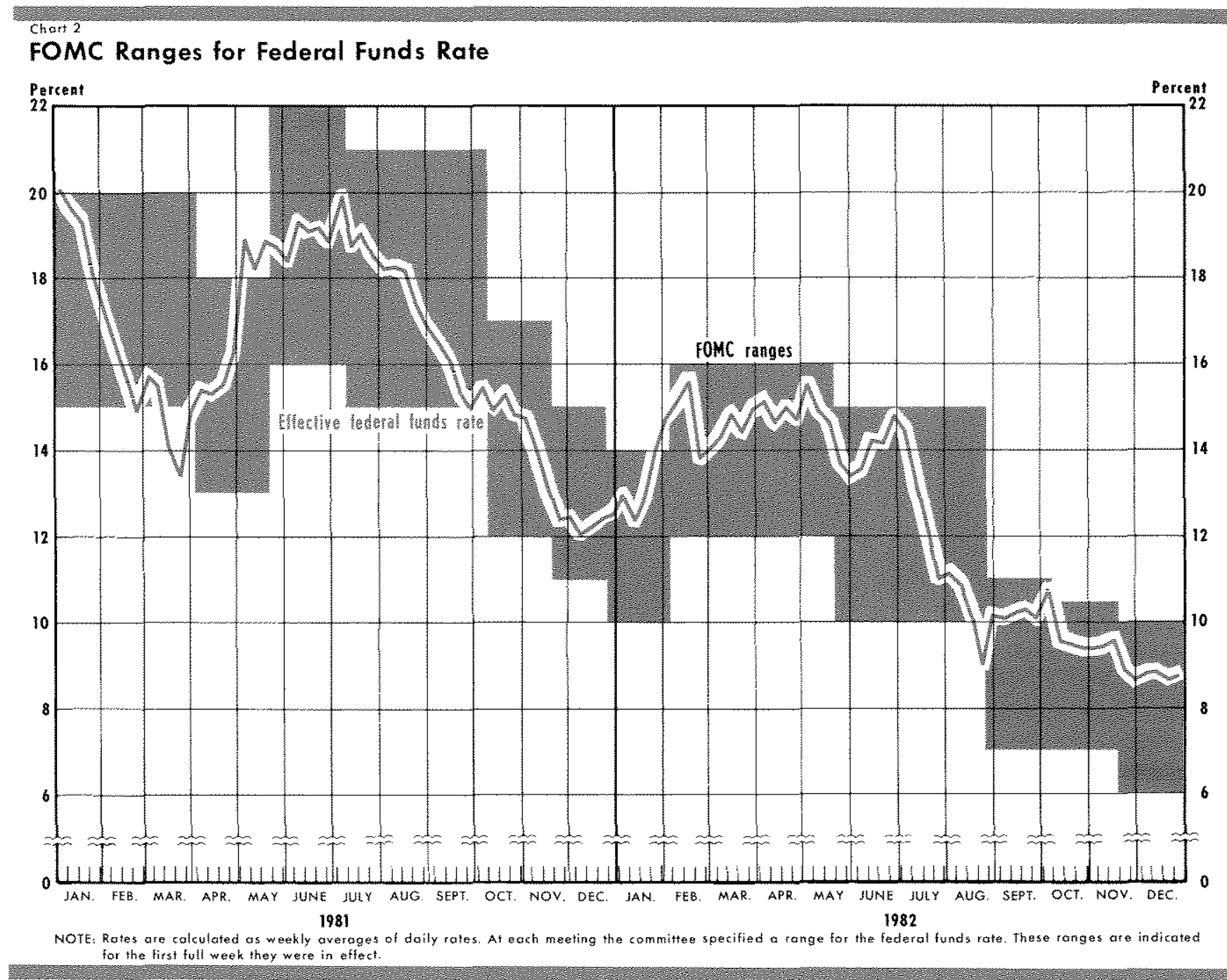

relative weight that should be given to $\mathrm{M} 1$ and $\mathrm{M} 2$ in implementing the Committee's short-run policy decisions. ${ }^{11}$ Indeed, the relative importance of $\mathrm{M} 2$ and Ml for short-run policy purposes shifted during the year.

Nevertheless, just as in 1981, short-run movements in the aggregates during 1982 followed their short-run target paths. This correspondence between the target paths and actual growth of the aggregates is illustrated in chart 3 , which shows the short-run target ranges and actual levels of M1 and M2, respectively, based on first-published data. First-published data give a more

\footnotetext{
${ }^{11}$ See Daniel L. Thornton, "The FOMC in 1981: Monetary Control in a Changing Financial Environment," this Review (April 1982), pp. $3-22$.

${ }^{12}$ Because of a definitional change, data for $\mathrm{M} 2$ prior to February 5 , 1982, are not first-published. Prior to that date, M2 included repurchase agreements and isntitution ${ }^{\circ}$ only money market mutual funds.
}

accurate representation of the Committee's short-run policy decisions based on information available at the time. ${ }^{12}$ Chart 3 shows that short-run targets for $\mathrm{M} 1$ were specified only for the first three quarters of the year. During its October meeting, the Committee decided to place much less weight than usual on the narrow aggregate and not set a specific objective for its growth. At this time, the Committee began setting short-run targets for M3.

\section{First Ouarter}

The short-run targets for the first quarter of 1982 were made against a backdrop of rapid expansion in M2 and M1 from November 1981. The growth of both monetary aggregates accelerated during January 1982 , especially that of M1. The Committee believed that the rapid growth in the demand for components of MI would abate during the ensuing months. It noted that if 
Charf 3

Short-Term and Long-Term Growth Objectives Based on First Published Data

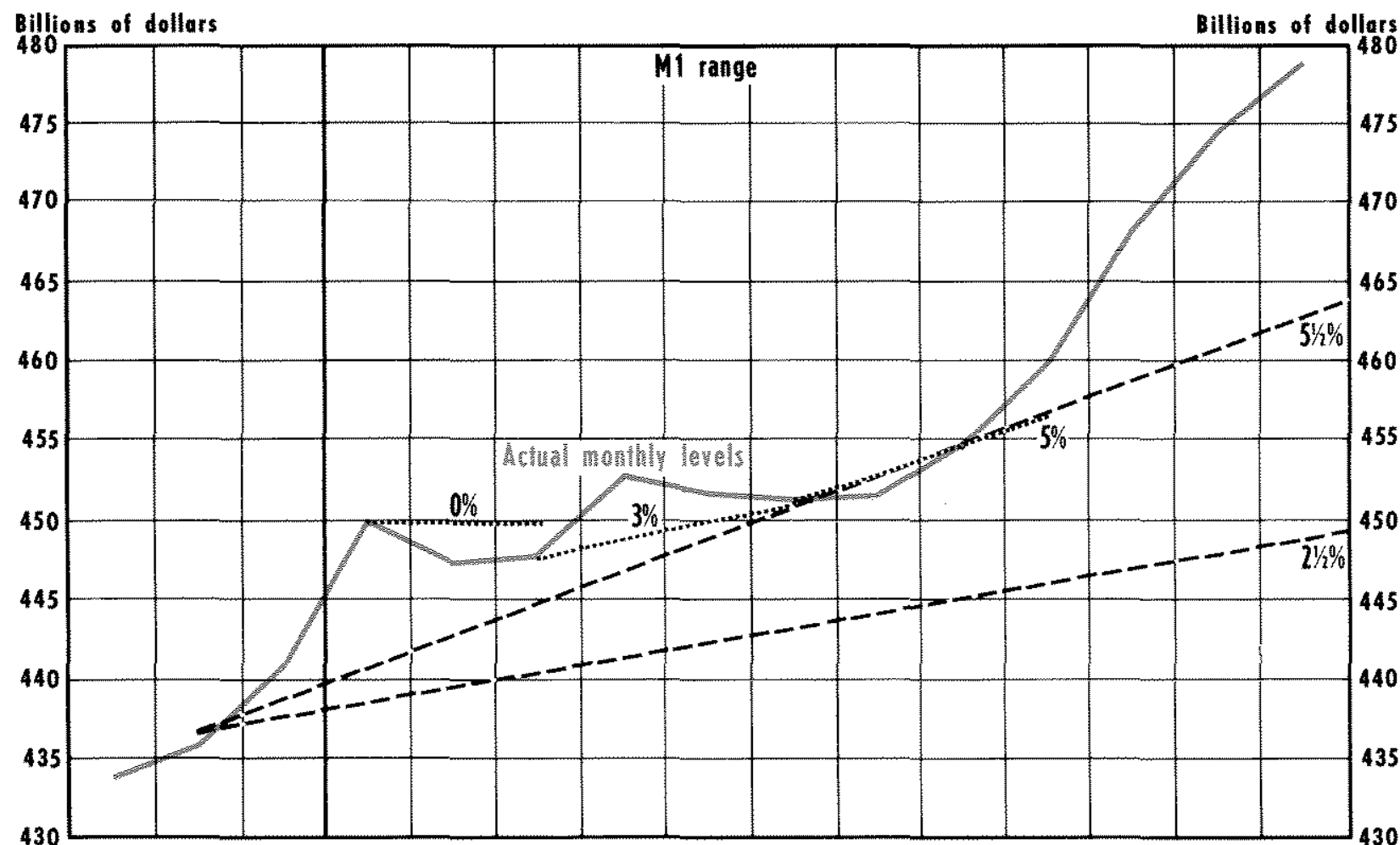

Billions of dollars

Billions of dollars
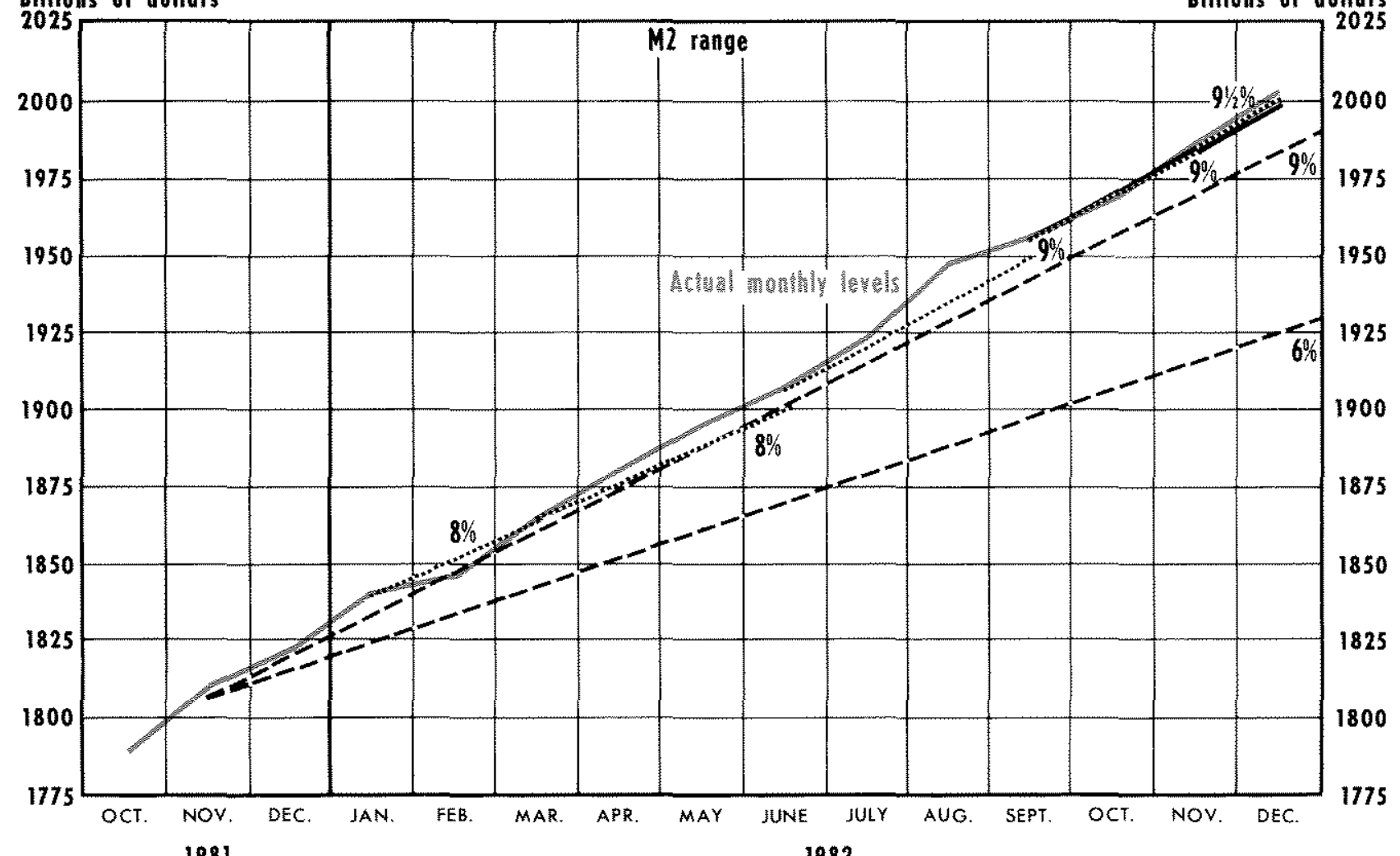

NOTE: Long dashed lines represent the long-term growth abjective for the period W/81. W/82. Short dashed lines repesent the current short-term grawth objectives. Date, except for $M 2$ published before $2 / 5 / 82$, ate first published trom the Board's H-6 releose. Prior to $2 / 5 / 82, M 2$ included RPs and institution-only MMMFs. 
such a decline were not forthooming, the income velocity of Ml would decline at a postwar record rate, based on the then-projected growth of nominal GNP for the first quarter. Thus, the Committee established growth paths for M1 and M2 that, if achieved, would move these aggregates closer to the upper limit of their annual target ranges. Specifically, the Committee sought no further growth in MI from January to March and growth of $\mathrm{M} 2$ at an annual rate of around 8 percent. It was agreed that some decline in M1 would be acceptable in the context of reduced pressures in the money market. $^{13}$

\section{second Qurrer}

Continued uncertainty about the relative behavior of $\mathrm{M} 1$ and $\mathrm{M} 2$ marked the short-run policy decisions for the second quarter. Staff analysis continued to suggest that the demand for money might be expected to moderate significantly in the second quarter. Furthermore, the Committee was concerned that technical problems associated with the federal income tax deadline in April might result in an April bulge in M1 growth. It was understood that most, if not all, of the MI growth for the second quarter might occur during April. ${ }^{14}$

Given these technical factors and given uncertainties about near-term economic prospects and other factors affecting the monetary aggregates, most members of the Committee favored actions that would permit modest growth in Ml over the second quarter. Thus, the Committee set a short-run target for M1 of about 3 percent, while maintaining the short-run target growth rate for M2 at its first-quarter rate. Furthermore, it noted that deviations from these targets should be evaluated in the light that $\mathrm{M} 2$ was less likely than M1 to be affected by deposit shifts and technical factors over the second quarter. ${ }^{15}$

\section{Third Outher}

In setting its short-run objectives for the third quarter, the Committee noted that the growth of MI and

\footnotetext{
${ }^{13}$ See "Record" (April 1982), p. 234.

${ }^{14}$ See "Record" (June 1982), p. 368.

15\% The Committee reevaluated its position for the second quarter at its May meeting. Most members agreed that somewhat more rapid growth of MI might be acceptable if it appeared to be associated with a continued desire of the public to build up liquidity, and if the growth of $\mathrm{M} 2$ was near its specified range. See "Record" (July 1982) . p. 420.
}

M2 for the whole period from March to June appeare to be in line with its objectives for that period (see cha: 3). The Committee was increasingly pessimistic, how ever, about the outlook for the economy, and it cor tinued to be concerned about the uncertainty over th public's demand for liquidity and precautionary ba ances. Additionally, it was concerned that the midyes reduction in withholding rates for federal income taxe and the scheduled cost-of-living increase in soci: security payments would lead to a bulge in Ml durin July. After a discussion of these factors, most of th Committee members agreed that they would accer somewhat faster monetary growth in the third quarte if the demand for liquidity and precautionary balance did not ease as anticipated. Thus, the Committe voted for faster growth for both M1 and M2 from th second to the third quarter, increasing the MI targe from about 3 percent to about 5 percent and increasin the M2 target from about 8 percent to about percent. ${ }^{16}$

\section{De-emphastang Wh $^{1}$}

At the October meeting, when the short-run objec tives for the fourth quarter were first considered, number of new considerations concerning the state $c$ the economy and financial markets emerged. Th Committee was concerned that the general worsenin of the world economy and financial problems associ ated with large accumulated external debts of develop ing countries in recent years had contributed to as atmosphere of uncertainty that was reflected in th exchange value of the dollar, among other things. This in turn, had serious implications for U.S. export indus tries and for the ability of foreign governments to pur sue flexible monetary policies. Also, the Committe was concerned that the U.S. banking system had been subjected to pressures associated with the general un easiness about further credit problems both domesti cally and internationally. The result was a genera widening of risk premiums, with interest rates on pri vate securities generally falling less than the rates or Treasury issues from July to September. It noted tha short-term interest rates had tended to move up in the weeks just before the meeting. Furthermore, the com mittee noted that the widely held expectations o a spring or summer recovery had been disappointed and there were no signs of a strengthening in the economy. ${ }^{17}$

\footnotetext{
16Three members dissented from this action because they favored a policy of bringing growth of $\mathrm{Ml}$ lown to its range for $1982 \mathrm{by}$ year"end. See table 1 or "Record" (September 1982), p. 548.

${ }^{17}$ See "Record" (December 1982), pp. 763-64.
} 
With respect to the monetary aggregates, the Committee faced two new concerns: First, a large volume of all-savers certificates would mature in early October. Second, later in the quarter, the Depository Institution Deregulation Committee (DIDC) would implement the Garn-St Germain Depository Institutions Act of 1982 and create an account that would be equivalent to and competitive with money market mutual funds. While the exact nature of this new account and the timing of its implementation were unknown in October, it was known that the new account would be free of interest rate ceilings and would have some degree of usefulness for transaction purposes. ${ }^{18}$

It was believed that the maturing all-savers certificates would induce a temporary increase in $\mathrm{Ml}$, while the new money market deposit accounts (MMDAs) would depress Ml growth upon their introduction. Because of these conflicting effects, the Committee believed it would be difficult to interpret movements in $\mathrm{Ml}$ during the months ahead. ${ }^{19}$ It acknowledged that the new accounts also would affect the growth of M2; however, it believed that M2 and the broader aggregates would be affected to a much smaller extent than M1. Therefore, it decided to set no specific objectives for M1 growth for the fourth quarter, to increase the weight given to $\mathrm{M} 2$ and to set short-run policy objectives for M3.

At the November meeting, the Committee acknowledged that the bulge in $M l$ growth, which it had anticipated, had persisted longer than some members expected, but staff analysis suggested $\mathrm{Ml}$ growth could be expected to decelerate over the remainder of the fourth quarter. It was noted, however, that growth of both M1 and M2 could accelerate in the near term due to a buildup of balances for eventual placement in the new MMDAs. ${ }^{20}$ The Committee concluded that some-

${ }^{18}$ At the time of this meeting (October 5), the Act had not been enacted (October 15). The Act required implementation of the new account no later than 60 days after taking effect.

There was, however, some reason to believe that the effect of the new money market deposit accounts (MMDAs) on M1 would be minimal. See John A. Tatom, "Money Market Deposit Accounts, Super-NOWs and Monetary Policy," this Review (March 1983), pp. $5-16$.

${ }^{20} \mathrm{By}$ this time, the Committee knew that MMDAs would become effective on December 14, 1982. See "Record" (January 1983), p. 19. what slower growth in M2 for the fourth quarter would be desirable if such growth were associated with a decline in market interest rates, and that somewhat faster growth would be tolerated if exceptional liquidity demands persisted. Once again, the Committee decided not to set specific policy objectives for M1.

The growth of M2 during the fourth quarter was very near the Committee's short-run objective (see chart 3). The growth of M1, however, was extremely rapid, growing at an annual rate of nearly 14 percent. This rapid fourth-quarter growth of $\mathrm{Ml}$ resulted in a fourthquarter-to-fourth-quarter growth rate of 8.5 percent, well above the upper end of the long-run target range for the year.

\section{SUMDAN}

As in 1981, the FOMC argued that a number of financial developments and innovations continued to make it difficult to interpret movements in the two principal monetary aggregates, $M 1$ and $M 2$, during 1982. From the beginning of the year, the Committee believed that M2 was less likely to be affected by these factors than M1. This opinion was bolstered by unusual declines in the income velocity of Ml during the first and fourth quarters of 1982 . It was generally felt that considerable weight should be given to $\mathrm{M} 2$ in interpreting developments during the year. The Committee increased the weight given to M2 during the year, ultimately dropping $\mathrm{Ml}$ as an explicit intermediate policy target for the fourth quarter.

Nevertheless, the growth of both M1 and M2 followed the short-run growth objectives of the Committee fairly closely during the year. Growth of MI was near the Committee's short-run path until the fourth quarter, when short-run growth objectives for the aggregate were dropped. Actual growth of M2 was near the Committee's desired short-run path for the entire year. Rapid fourth-quarter growth of M1, however, pushed its growth well above the Committee's long-run range.

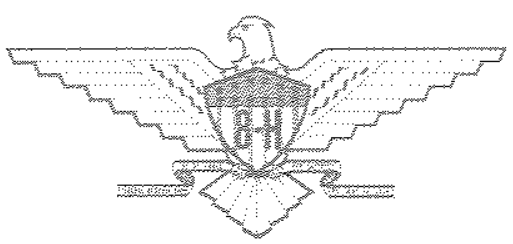

